\title{
Country-rock contamination of marginal mafic granulites bordering the Nain Plutonic Suite: implications for mobilization of Sr during high- grade contact metamorphism
}

\author{
K.R. Royse, S.R. Noble, J . Tarney, and A.C. Cadman
}

\begin{abstract}
The marginal mafic granulites that locally border the Nain Plutonic Suite (NPS) have a range of initial Ndisotope ratios that overlap with that of the NPS anorthosites and associated Nain dykes. The similarity in Nd-isotope data suggests that gneissic Archaean country rocks have contaminated all the anorthosites, marginal mafic granulites, and dykes. Sr-isotope data for the mafic granulites and dykes support a country rock contamination scenario but preclude wholesale assimilation of rocks such as the host Archaean tonalite gneisses as the sole contaminant. Initial $\varepsilon_{\mathrm{Sr}}$ values of +10 to +403 and +0.9 to +242 for the mafic granulites and dykes, respectively, are significantly higher than values for NPS country rocks examined thus far. The elevated initial $\varepsilon_{S \mathrm{r}}$ values are therefore interpreted to result from the introduction of radiogenic Sr into the granulites and dykes via Sr-rich fluids, generated by the breakdown of Rbrich mineral phases such as biotite in the country rocks during NPS.
\end{abstract}

\begin{abstract}
Résumé : Les granulites mafiques marginales, qui bordent localement la Suite plutonique de Nain, fournissent des variations de rapports isotopiques initiaux de Nd qui chevauchent les valeurs des anorthosites de la Suite plutonique de Nain, et des dykes associés dans la Province de Nain. Cette similitude des données isotopiques de Nd suggère que des roches gneissiques encaissantes archéennes ont contaminé toutes les anorthosites et les granulites mafiques marginales, et les dykes également. Les données isotopiques de $\mathrm{Sr}$ obtenues pour les granulites mafiques et les dykes plaident en faveur d'un scénario de contamination des roches encaissantes, mais elles excluent que l'unique mécanisme de contamination serait l'assimilation en gros des roches hôtes, par exemple les gneiss tonalitiques d'âge archéen. Les valeurs $\varepsilon_{\mathrm{Sr}}$ de +10 à +403 et de $+0,9$ à +242 que procurent les granulites mafiques et les dykes, respectivement, sont significativement plus élevées que les valeurs obtenues pour les roches encaissantes de la Suite plutonique de Nain qui ont été examinées jusqu'à présent. Les fortes valeurs des $\varepsilon_{\mathrm{Sr}}$ initiaux sont donc interprétées comme le résultat de l'ajout de $\mathrm{Sr}$ radiogénique dans les granulites et les dykes par les venues de fluides riches en $\mathrm{Sr}$, suite à la destruction des minéraux riches en $\mathrm{Rb}$, comme la biotite des roches encaissantes, durant la mise en place de la Suite plutonique de Nain.
\end{abstract}

[Traduit par la Rédaction]

\section{Introduction}

The petrogenesis of the anorthosite-dominated Nain Plutonic Suite (NPS) has been discussed by several workers but remains controversial (Morse 1982; Wiebe 1992; Emslie et al. 1994). Granulite-facies mafic rocks occur along the margin of the NPS and have been considered part of the host Archaean rocks and the NPS. Rocks similar to these have

Received May 20, 1998. Accepted February 8, 1999.

K.R. Royse. ${ }^{1}$ Department of Earth Sciences, Keele University, Keele, Staffordshire ST5 5BG, United Kingdom. S.R. Noble. Natural Environment Research Council, Isotope Geosciences Laboratory, Kingsley Dunham Centre, Keyworth, Nottingham NG12 5GG, United Kingdom.

J. Tarney and A.C. Cadman. Department of Geology, University of Leicester, University Road, Leicester LE1 7RH, United Kingdom.

${ }^{1}$ Corresponding author. Present address: The British Geological Survey, Kingsley Dunham Centre, Keyworth, Nottingham NG12 5GG, United Kingdom

(e-mail: krro@wpo.nerc.ac.uk). been credited with having played an important role in the petrogenesis of the anorthositic rocks (Emslie 1978a, 1978b, 1980; Morse 1982; Olson and Morse 1990). This study examines their field, geochemical, and $\mathrm{Sr}$ - and $\mathrm{Nd}$-isotope characteristics to better understand their relationship with the NPS. New Nd- and Sr-isotope data and geochemical data are presented for the marginal mafic granulites from the Jonathon and Nukasusutok island intrusions and compared with existing data from the NPS anorthosites (Hamilton 1993; Emslie et al. 1994) and associated Nain dykes (A.C. Cadman, unpublished data). On the basis of this new data, we propose that the mafic granulites are related to the NPS. Furthermore, Sr-isotope data indicate that the marginal granulites were also affected by significant contamination by a source of radiogenic Sr, similar to some NPS anorthosites.

\section{Regional geology}

The geology of northern and central Labrador comprises two major lithotectonic subdivisions: the Archaean Nain Province and the Proterozoic Churchill Province (Fig. 1) (Ermanovics et al. 1989; Wardle et al. 1990). The north- 
Fig. 1. Geological map of the Nain area, northeastern Labrador. C, Carey Island; D, Dog Island; J, Jonathon Island; M, Mary Island; N, Nukasusutok Island; S, Sandy Island. The inset map shows the regional tectonic framework of Labrador, displaying the main geological provinces (from Wardle et al. 1990). Numbers indicate sample locations for the marginal mafic granulites.

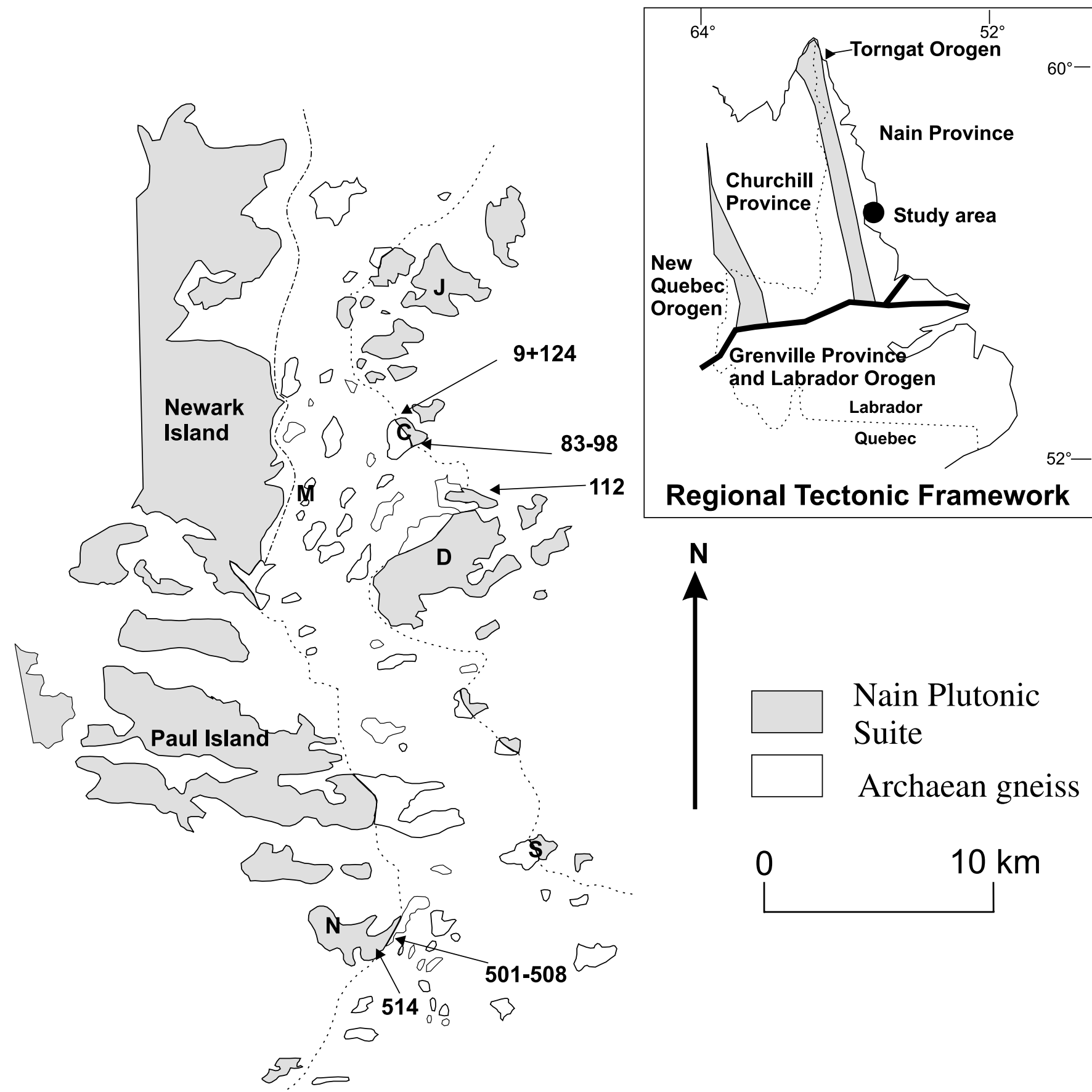

south boundary between the two provinces is marked by the ca. 1.8 Ga (Wardle et al. 1990) collisional Torngat Orogen. This collisional suture was intruded by a diverse array of plutonic rocks of anorthosite, troctolite, diorite, and granitic rocks (between 1.35 and $1.29 \mathrm{Ga}$ ) that make up the NPS (Morse 1971-1983; Ryan 1990; Ryan and Emslie 1994).

The Churchill Province boundary with the Nain Province consists of a band of garnetiferous gneisses known as the Tasiuyak gneisses (Wardle et al. 1990), spatially coincident with the collisional Torngat Orogen. Much of the Churchill Province consists of reworked Archaean basement. East of the Churchill Province lies the Archaean Nain Province (3.8-2.7 Ga) consisting largely of high-grade gneisses, representing the Labrador segment of the North Atlantic Craton. These gneisses can be split into two blocks according to their structural and lithological affinities and geochronology: the Saglek Block in the north and the Hopedale Block in the south (Fig. 1). The blocks have distinct lithological and tectonic histories (Bridgwater and Schiøtte 1991) until the late Archaean (ca. 2.57 Ga), suggesting that they were separate terranes until this time (Connelly and Ryan 1996). 
Pioneering work by Wheeler $(1942,1960)$ showed that the NPS was a polyphase batholithic igneous terrane. Later detailed studies of the Nain Anorthosite Project (Morse 19711983; Emslie et al. 1972; Taylor 1979; Emslie 1980; Morse 1982) revealed a diversity of compositions and intrusive forms (e.g., bulbous, saucer-shaped layered intrusions and large dykes) and identified multiple intrusive events within superficially simple plutonic units, the accepted nomenclature of which is summarized by Ryan (1990). A contactmetamorphic aureole adjacent to the NPS (Berg 1977) is locally developed within the country-rock gneisses and mafic enclaves. Paragneisses in the contact aureole contain cordierite and spinel pseudomorphs after sillimanite, indicative of pyroxene-hornfels facies metamorphism.

The anorthosites within the Grenville and northern Labrador are characterized by light rare earth elements (REE) enrichment, positive Eu anomalies (Ashwal and Seifert 1980), and a consistent slope to the heavy REE. In contrast, some leucogabbros have high total REE abundances and no $\mathrm{Eu}$ anomaly (Watson 1979). The margins of many of the anorthosite intrusions show enrichment in large ion lithophile elements (LILE), consistent with crustal contamination (Emslie et al. 1994). Noritic (orthopyroxene-bearing) plutons isotope signature reflects a greater crustal component than the more olivine-rich varieties (Emslie et al. 1994; Ashwal and Wooden 1983).

\section{Mafic granulites}

Granulite-facies mafic rocks occur as enclaves in the gneisses that host the NPS and as larger bodies that locally border the NPS anorthosites (Wheeler 1942; Ryan 1991, 1993; Berg et al. 1994; Royse and Ryan 1995). The origin of these mafic granulites has been the subject of considerable debate, and in particular whether they are a component of the country rocks or the NPS (Isachsen 1968; Nolan and Morse 1986; Olson and Morse 1990). During the course of this study, the mafic granulites immediately bordering the NPS, herein referred to as the marginal mafic granulites, were found to differ from mafic granulite enclaves occurring more distal to the NPS in the host rock gneisses in that the former retain their primary textures, such as well-developed igneous layering. In addition, the marginal mafic granulites are unmetamorphosed and do not contain podiformed hornblende.

Two marginal mafic granulite suites are examined here: the southwestern margin of the Jonathon Island intrusion, and the eastern margin of the Nukasusutok Island intrusion (Fig. 1). Other similar marginal granulites occur at Moskie Island, Myrtle Island, Mary Island (which also form the outer marginal zone of the Newark Island intrusion, Fig. 1), and the eastern side of the Paul Island intrusion.

The southwestern margin of the Jonathon Island intrusion is best exposed on Carey Island (Royse and Ryan 1995). The contact between the marginal mafic granulites and the anorthosites is diffuse, suggesting that the marginal mafic granulites and anorthosites are components of the same intrusive body. The composition of the marginal mafic granulites ranges from olivine gabbro-norite to olivine norite. Within the unit there are inclusions and rafts of paragneisses, quartzo-feldspathic rocks, and older hornblenderich mafic granulite, as well as brecciated fragments of leuconorite. The marginal mafic granulites show welldeveloped igneous layering that is locally chaotic and display slump folding. Large orthopyroxene pods and pegmatitic xenoliths of leuconorite disrupt the layering within the marginal series. The unit and the outer border zone of the Kiglapait intrusion (Nolan and Morse 1986) share a number of similar characteristics (i.e., both are granulitic olivine gabbro-norites with locally chaotic layering).

The marginal mafic granulites occurring along the western margin of the Nukasusutok Island intrusion make up a layered unit of olivine norite. The layering in this unit is not as chaotic as that observed in the Jonathon Island marginal mafic granulites. Recrystallized mafic dykes that are discordant to the primary igneous layering have a strong foliation parallel to the pervasive foliation in the layered olivine norite, indicating predeformation emplacement of the layered olivine norite and the dykes. The marginal mafic granulites are clearly earlier than the Nukasusutok Island anorthosite intrusion to the west, which is not crosscut by mafic dykes. The original igneous textures in the marginal mafic granulites, however, serve to distinguish the unit from older granulite mafic bodies occurring in the Archaean country rocks.

\section{Nain dykes}

Archaean gneisses that form the country rocks to the NPS are intruded by a variety of metamorphosed mafic dykes (Ryan 1995; Cadman and Ryan 1994). Dyke emplacement probably took place during three episodes at ca. $2560 \mathrm{Ma}$ (cf. Connelly and Ryan 1994), ca. 2.05 Ga (Connelly and Ryan 1993), and between 1328 and $1316.5 \mathrm{Ma}$, the time when the latest and predominant group intruded (Cadman et al. 1999). The last group of metamorphosed dykes is probably directly associated with NPS emplacement and possibly represents leaks from NPS feeder chambers (Cadman et al. 1999).

The textures of the main 1328-1316.5 Ma group of dykes (referred to as Nain dykes) vary from diabasic to granular to strongly foliated, although massive to porphyritic types are also present. Cadman et al. (1999) described three principal varieties of Nain dykes: black two-pyroxene-hornblende dykes, grey two-pyroxene dykes, and black amphibolite dykes. Crosscutting relationships indicate that the dykes were intruded over the same time period.

\section{Marginal mafic granulite geochemistry}

Major and trace element data, in addition to Sr- and Ndisotope data, were obtained on the marginal mafic granulites to characterize their composition and permit comparison with the adjacent confirmed NPS and country-rock gneisses.

\section{Analytical methods}

Fresh representative whole rock samples were trimmed, jaw crushed, and ground to a fine flour in an agate mill. Major element compositions were determined on fused discs using $\mathrm{Rh}$ anode excitation, and the trace elements $\mathrm{Sc}, \mathrm{V}, \mathrm{Cr}$ $\mathrm{Ni}, \mathrm{Zn}, \mathrm{Ga}, \mathrm{Rb}, \mathrm{Sr}, \mathrm{Y}, \mathrm{Zr}, \mathrm{Nb}, \mathrm{La}, \mathrm{Ce}, \mathrm{Nd}$, and Ba were measured on pressed powder briquettes using either Rh or W excitation on a Phillips PW1600 X-ray fluorescence spectrometer (for techniques see Marsh et al. 1983). 
Samples analyzed for their isotope compositions were digested in PFA Teflon vessels using $\mathrm{HF}-\mathrm{HNO}_{3}$. $\mathrm{Rb}, \mathrm{Sr}, \mathrm{Sm}$, and $\mathrm{Nd}$ concentrations were determined by isotope dilution using enriched ${ }^{85} \mathrm{Rb},{ }^{84} \mathrm{Sr}$, and mixed ${ }^{149} \mathrm{Sm} /{ }^{150} \mathrm{Nd}$ isotope tracer solutions. $\mathrm{Rb}, \mathrm{Sr}$, and the REE were separated by eluting distilled $2.5 \mathrm{M}$ and $6.2 \mathrm{M} \mathrm{HCl}$ through AG50-X8 cation exchange resin in quartz columns. Sm and $\mathrm{Nd}$ were purified by reverse-phase chromatography in quartz columns, using a $0.2 \mathrm{M}$ and $0.6 \mathrm{M} \mathrm{HCl}$ elution. All Sr-isotope results were obtained on a MAT262 mass spectrometer via static multicollection in two different periods, during which analyses of NBS987 yielded ${ }^{87} \mathrm{Sr} /{ }^{86} \mathrm{Sr}=0.710202 \pm 22(1 \sigma$, $n=29)$ and $0.710211 \pm 20(1 \sigma, n=21)$, respectively. Smand $\mathrm{Nd}$-isotope data were obtained on the Nerc Isotope Geoscience Laboratories (NIGL) VG354 and MAT262 mass spectrometers via static multicollection. During the course of analysis on the VG354 the La Jolla international standard yielded ${ }^{143} \mathrm{Nd} /{ }^{144} \mathrm{Nd}=0.511853 \pm 9(1 \sigma, n=48)$. Repeated analyses of an NIGL internal standard prepared from Johnson and Matthey $\mathrm{Nd}_{2} \mathrm{O}_{3}$ gave ${ }^{143} \mathrm{Nd} /{ }^{144} \mathrm{Nd}=0.511125 \pm 7$ $(1 \sigma, n=82)$ on the VG354, and ${ }^{143} \mathrm{Nd} /{ }^{144} \mathrm{Nd}=0.511134 \pm 18$ $(1 \sigma, n=52)$ on the MAT262. The standard data indicate that there is no significant systematic bias for data obtained on the two mass spectrometers. Total analytical blanks were $<<200 \mathrm{pg}$ and $<<500 \mathrm{pg}$ for $\mathrm{Nd}$ and $\mathrm{Sr}$, respectively. Mass fractionation corrections were made relative to ${ }^{86} \mathrm{Sr} /{ }^{88} \mathrm{Sr}=$ 0.1194 and ${ }^{146} \mathrm{Nd} /{ }^{144} \mathrm{Nd}=0.7219$. The ${ }^{87} \mathrm{Rb}$ and ${ }^{147} \mathrm{Sm}$ decay constants used here are $1.42 \times 10^{-12} \mathrm{a}^{-1}$ and $6.54 \times 10^{-12} \mathrm{a}^{-1}$ (Stager and Jäger 1977; Langmuir et al. 1978). Calculations of $\varepsilon_{\mathrm{Nd}}(t), T_{\mathrm{CHUR}}$, and $T_{\mathrm{DM}} ;\left({ }^{143} \mathrm{Nd} /{ }^{144} \mathrm{Nd}\right)_{\mathrm{CHUR}}=0.512638$, $\left({ }^{143} \mathrm{Nd} /{ }^{144} \mathrm{Nd}\right)_{\mathrm{DM}}=0.5131,\left({ }^{147} \mathrm{Sm} /{ }^{144} \mathrm{Nd}\right)_{\mathrm{CHUR}}=0.1967$, and $\left({ }^{147} \mathrm{Sm} /{ }^{144} \mathrm{Nd}\right)_{\mathrm{DM}}=0.225$ (McCulloch et al. 1985), were calculated following DePaolo (1981).

\section{Results}

\section{Major element geochemistry}

$\mathrm{SiO}_{2}$ contents of the marginal mafic granulites vary from 42 to 61 weight percent (wt.\%) and magnesium numbers (Mg\#) range from 20 to 75 (Table 1). For comparison, the 1316.5-1328 Ma Nain dykes have $\mathrm{SiO}_{2}$ values from 42 to 58 wt.\% with $\mathrm{Mg \#}$ from 31 to 85 (Table 1). The marginal mafic granulites and the dykes within the area have relatively high $\mathrm{Al}_{2} \mathrm{O}_{3}$ and $\mathrm{Fe}_{2} \mathrm{O}_{3}$ values, the majority of which lie in the range 5-15 and 11-18 wt.\%, respectively. Most of the marginal mafic granulites and the dykes are Fe basalts, as defined by Shirey and Hanson (1986), but they have notably higher Al contents than typical Fe-Ti basalts. Similar AlFe-rich mafic rocks have been noted in other anorthositebearing terranes by Olson and Morse (1990).

In comparison to the marginal mafic granulites, the anorthosite silica values (Hamilton 1993; Emslie et al. 1994) typically range from 42.3 to 69.9 wt. $\%, \mathrm{Al}_{2} \mathrm{O}_{3}$ values range between 29.8 and 10.5 wt.\%, and $\mathrm{Mg \#}$ between 13 and 70 . $\mathrm{Rb} / \mathrm{Sr}$ ratios are low, ranging from 1.000 to 0.003 , and suggest that the plutons in the NPS have undergone large-scale differentiation since separation from the parental magma.

\section{Trace element geochemistry}

Trace element concentrations for the marginal mafic granulites, anorthosites, and the Nain dykes are listed in Ta- ble 1 and plotted on trace element distribution plots in Figs. 2a-2e. The marginal mafic granulites from the Jonathon Island intrusion have negative $\mathrm{Nb}$ anomalies, with a positive anomaly in $\mathrm{Sr}$ (Fig. $2 a$ ), whereas the layered olivine norite from Nukasusutok Island (Fig. 2b) has positive $\mathrm{Ba}, \mathrm{Nb}$, and $\mathrm{Sr}$ anomalies.

The anorthosites have trace element distribution patterns (Fig. 2c) that reflect the plagioclase-rich nature of these rocks (Duchesne 1978; Xue and Morse 1993; Emslie et al. 1994). They are all enriched in Ba, K, La, Ce, Sr, and $\mathrm{Nd}$ compared to primitive mantle. The low overall abundance of REE and a positive Eu anomaly for the anorthosites are consistent with the accumulation of plagioclase (Emslie et al. 1994).

Not all trace element characteristics in the anorthosites can be attributed to differences in cumulus mineralogy. For example, decreases in $\mathrm{Y}$ associated with decreasing magnitude of $\mathrm{Eu}$ anomalies cannot be accounted for by the accumulation of olivine and pyroxene and therefore must reflect the parental magma or source from which the anorthosites were derived. In addition, the observed $\mathrm{Rb}, \mathrm{Ba}$, and $\mathrm{Sr}$ contents cannot be accounted for in light of the distribution coefficients for plagioclase and, therefore, must be a characteristic of the magma source (Xue and Morse 1993).

Cadman et al. (1993, 1995) and Cadman and Ryan (1994) have described the geochemistry of the Nain dykes in detail. The dykes can be divided into two chemical groups on the basis of their high field strength elements (types A and B). These two chemically distinct groups are not distinguishable on the basis of their field characteristics, particularly with respect to inconsistent relative ages as determined by crosscutting relationships of the dykes within the study area. Multielement plots of group A dykes indicate enrichment in elements from $\mathrm{Nb}$ to $\mathrm{Nd}$ and depletion in $\mathrm{Y}$ (Fig. $2 d$ ) compared with group B dykes (Fig. 2e). Group B dykes (Fig. 2e) have relatively flat multielement profiles with slightly negative $\mathrm{Nb}$ anomalies, and fractionation of $\mathrm{La}$ and $\mathrm{Ce}$, due to the accumulation of mafic minerals such as olivine and pyroxene. A positive $\mathrm{Rb}$ anomaly, as measured against $\mathrm{Ba}$ abundance, is found for some dykes in group B and is probably a metamorphic effect (Pearce 1983).

\section{Isotope geochemistry}

The marginal mafic granulites of the Jonathon Island intrusion have initial $\varepsilon_{\mathrm{Sr}(1317 \mathrm{Ma})}$ ranging from +54 to $+403(\mathrm{Ta}-$ ble 2), and layered olivine norites from Nukasusutok Island have initial $\varepsilon_{\mathrm{Sr}}$ ranging from +10 to +384 . These values are considerably more radiogenic than bulk Earth at $1317 \mathrm{Ma}$ $\left({ }^{87} \mathrm{Sr} /{ }^{86} \mathrm{Sr}_{\mathrm{i}}=0.7029\right.$; Taylor and McLennan, 1981). In contrast to the $\mathrm{Sr}$-isotope data, the $\mathrm{Nd}$-isotope data show a significantly more limited range of $\varepsilon_{\mathrm{Nd}}$ values. The marginal mafic rocks of the Jonathon Island intrusion have $\varepsilon_{\mathrm{Nd}(1317 \mathrm{Ma})}$ values from +0.3 to -17.0 , whereas the layered olivine norite from Nukasusutok Island has values from -4 to -11 (Table 2).

\section{Discussion}

\section{Isotope geochemistry}

Regional Sr- and Nd-isotope studies on the anorthosites of the eastern Canadian Shield reveal a good correlation be- 
Table 1. Marginal mafic granulites: $\mathrm{Sm} / \mathrm{Nd}$ and $\mathrm{Rb} / \mathrm{Sr}$ isotope data.

\begin{tabular}{|c|c|c|c|c|c|c|c|c|c|c|c|c|c|c|c|}
\hline $\begin{array}{l}\text { Sample } \\
\text { No. }\end{array}$ & $\begin{array}{l}\mathrm{Sm} \\
(\mathrm{ppm})^{a}\end{array}$ & $\begin{array}{l}\mathrm{Nd} \\
(\mathrm{ppm})^{a}\end{array}$ & $\frac{{ }^{147} \mathrm{Sm}}{{ }^{144} \mathrm{Nd}}$ & $\frac{{ }^{147} \mathrm{Nd}^{b}}{{ }^{144} \mathrm{Nd}}$ & $\frac{{ }^{143} \mathrm{Nd}}{{ }^{144} \mathrm{Nd}}$ & $\varepsilon_{\mathrm{Nd}}(0)$ & $\begin{array}{l}\mathcal{E}_{\mathrm{Nd}} \\
(1317 \mathrm{Ma})\end{array}$ & $T_{\mathrm{CHUR}}$ & $T_{\mathrm{DM}}$ & $\begin{array}{l}\mathrm{Sr}^{a} \\
(\mathrm{ppm})\end{array}$ & $\begin{array}{l}\mathrm{Rb}^{a} \\
(\mathrm{ppm})\end{array}$ & $\frac{{ }^{87} \mathrm{Rb}}{{ }^{86} \mathrm{Sr}}$ & $\frac{{ }^{87} \mathrm{Sr}}{{ }^{86} \mathrm{Sr}}$ & $\frac{{ }^{87} \mathrm{Sr}}{{ }^{86} \mathrm{Sr}_{\mathrm{i}}}$ & $\begin{array}{l}\varepsilon_{\mathrm{Sr}} \\
(1317 \mathrm{Ma}) \\
\end{array}$ \\
\hline D9 & 3.42 & 14.25 & 0.1451 & 0.145058 & $0.511317 \pm 7$ & -25.77 & -17.08 & 3856 & 3939 & 239.60 & 6.35 & 0.076792 & 0.722884 & 0.721434 & 263.45 \\
\hline $\mathrm{D} 9^{c}$ & 4.45 & 18.29 & 0.1471 & 0.147054 & $0.511326 \pm 6$ & -25.59 & -17.24 & 3982 & 4051 & & & & & & \\
\hline D83 & & & & & & & & & & 564.18 & 4.09 & 0.020988 & 0.708479 & 0.708083 & 73.50 \\
\hline D84 & 1.64 & 5.12 & 0.1935 & 0.193507 & $0.512648 \pm 15$ & 0.20 & 0.73 & $\complement^{d}$ & $-^{d}$ & 79.94 & 2.74 & 0.099234 & 0.710780 & 0.708907 & 85.22 \\
\hline D88 & 2.54 & 5.79 & 0.2655 & 0.265544 & $0.513249 \pm 16$ & 11.92 & 0.34 & 1355 & 583 & 99.97 & 0.61 & 0.017812 & 0.731621 & 0.731285 & 403.58 \\
\hline D98 & 2.81 & 8.48 & 0.2001 & 0.200143 & $0.512478 \pm 7$ & -3.12 & -3.70 & $-^{d}$ & $-^{d}$ & 269.60 & 0.19 & 0.002027 & 0.706758 & 0.706720 & 54.11 \\
\hline N501 & 1.71 & 6.44 & 0.1607 & 0.160647 & $0.512119 \pm 19$ & -10.12 & -4.06 & 2177 & 2663 & 291.61 & 0.42 & 0.004215 & 0.703727 & 0.703647 & 10.40 \\
\hline N503 & 1.93 & 7.98 & 0.1465 & 0.146493 & $0.511833 \pm 4$ & -15.70 & -7.26 & 2426 & 2752 & 322.86 & 0.23 & 0.002057 & 0.706256 & 0.706217 & 46.96 \\
\hline $\mathrm{N} 505^{c}$ & 2.85 & 11.63 & 0.1483 & 0.148290 & $0.511856 \pm 6$ & -15.25 & -7.11 & 2444 & 2776 & 299.32 & 0.45 & 0.004383 & 0.706069 & 0.705986 & 43.68 \\
\hline N506 & 1.82 & 7.44 & 0.1481 & 0.148132 & $0.511726 \pm 7$ & -17.79 & -9.62 & 2837 & 3090 & 303.62 & 3.24 & 0.030890 & 0.709766 & 0.709183 & 89.15 \\
\hline N507 & 6.65 & 28.61 & 0.1405 & 0.140523 & $0.511566 \pm 8$ & -20.91 & -11.46 & 2885 & 3102 & 243.93 & 1.24 & 0.014752 & 0.730243 & 0.729965 & 384.80 \\
\hline N508 & 3.65 & 13.93 & 0.1582 & 0.158198 & $0.511932 \pm 3$ & -13.77 & -7.29 & 2771 & 3091 & 247.34 & 0.15 & 0.001712 & 0.711317 & 0.711285 & 119.05 \\
\hline N532 & 3.76 & 11.79 & 0.1930 & 0.192983 & $0.512591 \pm 8$ & -0.92 & -0.29 & 1839 & $-^{d}$ & 198.53 & 2.57 & 0.037378 & 0.705645 & 0.704939 & 28.78 \\
\hline $\mathrm{N} 532^{c}$ & 3.68 & 11.46 & 0.1941 & 0.194105 & $0.512595 \pm 8$ & -0.84 & -0.40 & 2397 & $\simeq^{d}$ & & & & & & \\
\hline $\mathrm{N} 536^{c}$ & 0.89 & 3.73 & 0.1451 & 0.145096 & $0.511862 \pm 8$ & -15.14 & -6.45 & 2276 & 2625 & 440.84 & 0.71 & 0.004646 & 0.703401 & 0.703313 & 5.65 \\
\hline
\end{tabular}

Notes: All $\mathrm{Rb} / \mathrm{Sr}$ data were obtained on a MAT262 mass spectrometer in two different periods, during which analyses of NBS987 yielded $0.710202 \pm 22\left({ }^{87} \mathrm{Sr} /{ }^{86} \mathrm{Sr}, 1 \sigma, n=29\right)$ and $0.710211 \pm 20(1 \sigma, n=21)$. Nd data were obtained on both a MAT262 and a VG354 mass spectrometer. During the course of analysis on the VG354 the LaJolla standard yielded ${ }^{143} \mathrm{Nd} /{ }^{144} \mathrm{Nd}=0.511853 \pm 9(1 \sigma, n=48)$. An NIGL internal standard gave ${ }^{143} \mathrm{Nd} /{ }^{144} \mathrm{Nd}=0.511125 \pm 7(1 \sigma, n=82)$ on the VG354, and during the same period data from the MAT262, gave ${ }^{143} \mathrm{Nd} /{ }^{144} \mathrm{Nd}=0.511134 \pm 18(1 \sigma, n=52)$. Duplicates listed above were measured for separate dissolutions and show that no bias was detectable for data obtained on the two mass spectrometers. Blanks during the course of analyses were $<200 \mathrm{pg} \mathrm{Nd}$ and $<500 \mathrm{pg} \mathrm{Sr}$.

${ }^{a} \mathrm{Sm}$ and $\mathrm{Nd}$ concentration data were obtained by isotope dilution and measured to a precision of $\pm 0.1 \%$ ( $2 \sigma$ ), and $\mathrm{Rb}$ and $\mathrm{Sr}$ concentrations were measured by $\mathrm{X}$-ray fluorescence to a precision of $\pm 0.5 \%$.

${ }^{b}$ Present-day ${ }^{143} \mathrm{Nd} /{ }^{144} \mathrm{Nd}$ ratios; errors are \pm 2 standard errors of the mean.

'Sample run on the MAT262 mass spectrometer. Other samples were run on the VG354 mass spectrometer.

${ }^{d}$ Model ages greater than $4.5 \mathrm{Ga}$ or less than $0 \mathrm{Ga}$ obtained when $\varepsilon_{\mathrm{Nd}(0 \mathrm{Ma})}$ is greater that 0 and ${ }^{147} \mathrm{Sm} /{ }^{144} \mathrm{Nd}$ is significantly greater than approx. 0.1000 . 
Fig. 2. Multielement diagrams for the mafic rocks bordering the Jonathon Island intrusion $(a)$, the layered olivine norite from Nukasusutok Island $(b)$, the anorthosites of the NPS $(c)$, and group A $(d)$ and group B $(e)$ mafic dykes associated with the Nain Plutonic Suite (Cadman et al. 1999). Mantle-normalized values after Taylor and McLennan (1981).

(a)

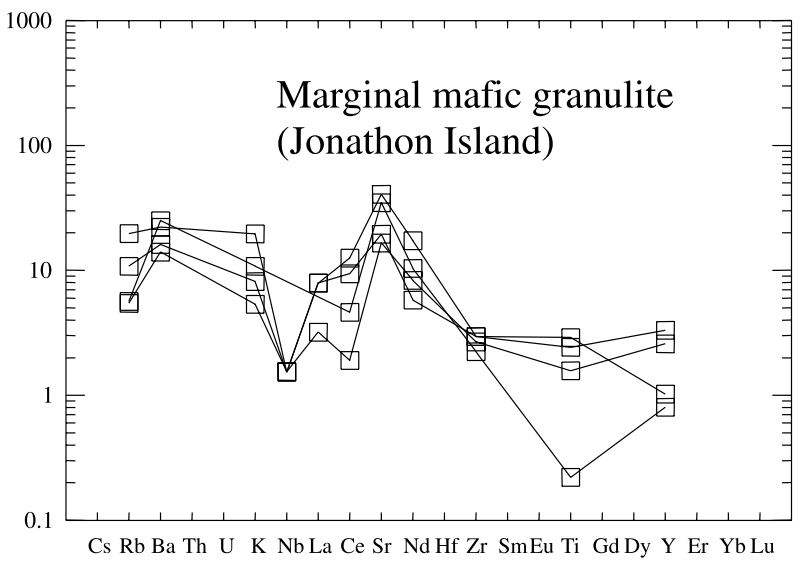

(b)

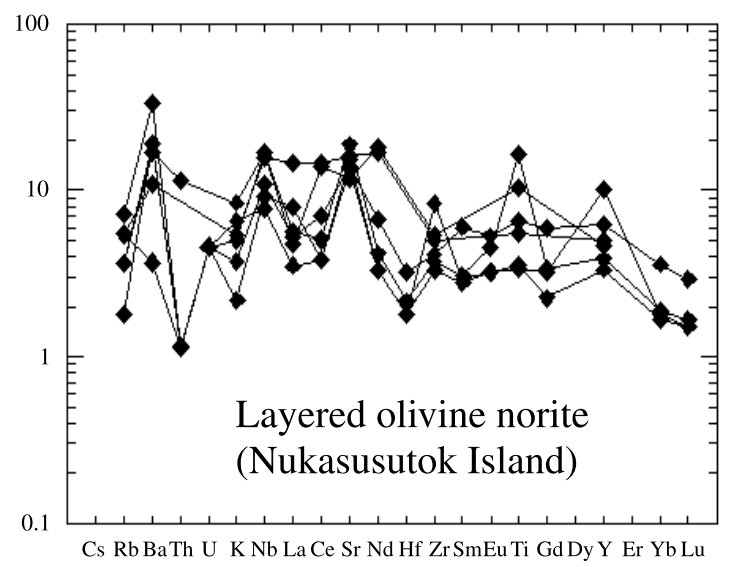

(c)

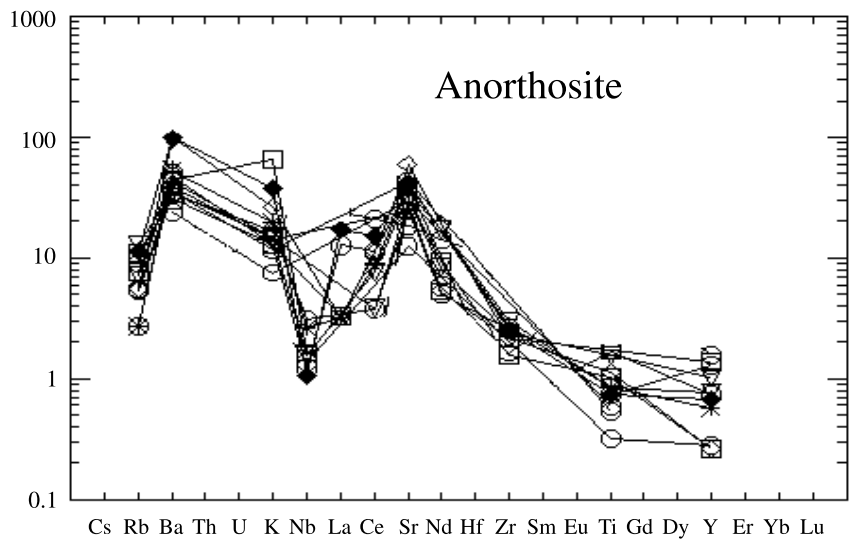

(d)

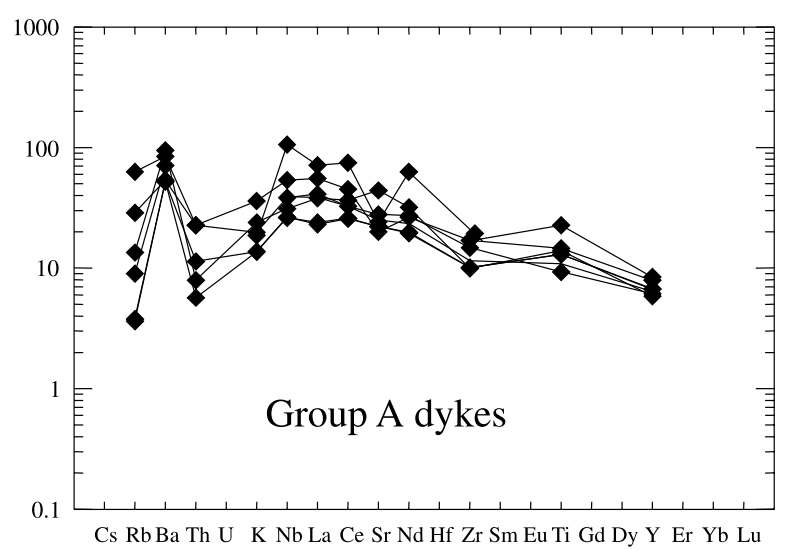

(e)

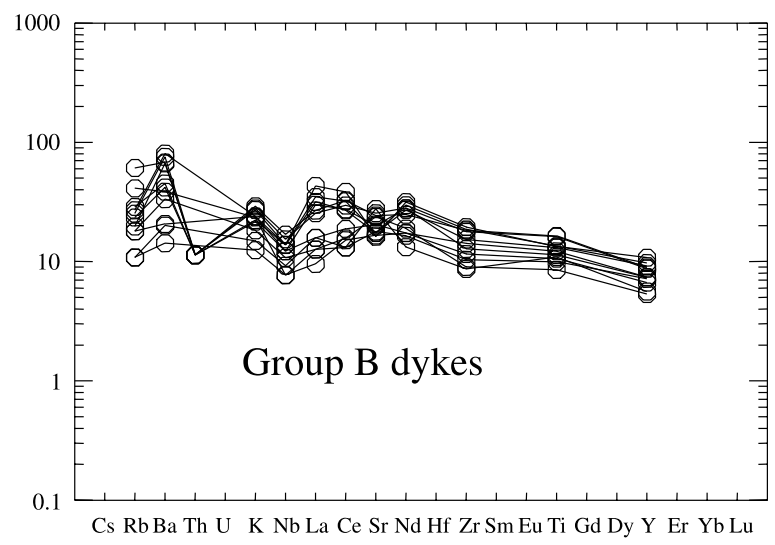

tween geographic location (i.e., basement composition) and initial isotopic compositions of the anorthosites (Hamilton 1993). Proterozoic anorthosites northwest of the Grenville front have significantly different isotopic signatures than those within the Grenville Province (Emslie et al. 1994). The isotopic signature of the NPS exhibits the same correlation and is profoundly influenced by the crustal signatures of the host province to the extent that the location of the NainChurchill boundary can be inferred from differences in the
$\mathrm{Nd}$ isotopic ratios of the NPS anorthositic plutons (Hamilton 1993).

In general, the range of initial $\varepsilon_{\mathrm{Sr}}$ and $\varepsilon_{\mathrm{Nd}}$ values obtained for the marginal mafic granulites significantly overlaps with data obtained elsewhere in the NPS and the host gneisses (Table 3; Fig. 4), although in detail there are some important differences. $\varepsilon_{\mathrm{Sr}}$ values for the NPS anorthosite range between +9 and +45 at $1317 \mathrm{Ma}$ (Hamilton and Shirey 1992; Hamilton 1993) and show that the majority of NPS rocks (i.e., 
Table 2. Isotope data for the Mesoproterozoic Nain dykes.

\begin{tabular}{|c|c|c|c|c|c|c|c|c|c|c|c|c|c|c|c|c|}
\hline $\begin{array}{l}\text { Sample } \\
\text { No. } \\
\end{array}$ & $\begin{array}{l}\text { Sm } \\
(\mathrm{ppm})^{a}\end{array}$ & $\begin{array}{l}\mathrm{Nd} \\
(\mathrm{ppm})^{a}\end{array}$ & ${\frac{147}{{ }^{144} \mathrm{Nd}}}^{b}$ & $\frac{{ }^{147} \mathrm{Nd}}{{ }^{144} \mathrm{Nd}}$ & $\frac{{ }^{143} \mathrm{Nd}}{{ }^{144} \mathrm{Nd}}$ & $\begin{array}{l}\varepsilon_{\mathrm{Nd}} \\
(0)\end{array}$ & 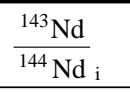 & $\begin{array}{l}\varepsilon_{\mathrm{Nd}} \\
(1317 \mathrm{Ma})\end{array}$ & $T_{\text {CHUR }}$ & $T_{\mathrm{DM}}$ & $\begin{array}{l}\mathrm{Sr}^{a} \\
(\mathrm{ppm})\end{array}$ & $\begin{array}{l}\mathrm{Rb}^{a} \\
(\mathrm{ppm})\end{array}$ & $\frac{{ }^{87} \mathrm{Rb}}{{ }^{86} \mathrm{Sr}}$ & $\frac{{ }^{87} \mathrm{Sr}}{{ }^{86} \mathrm{Sr}}$ & $\frac{{ }^{87} \mathrm{Sr}}{{ }^{86} \mathrm{Sr}_{\mathrm{i}}}$ & $\begin{array}{l}\varepsilon_{\mathrm{Sr}} \\
(1317 \mathrm{Ma}) \\
\end{array}$ \\
\hline N26-92 & 7.925 & 40.470 & 0.1184 & 0.118346 & 0.511426 & -23.64 & 0.510402 & -10.46 & 2347.07 & 2469.99 & 238.9 & 66.83 & 0.811542 & 0.735252 & 0.719932 & 242.08 \\
\hline N39-92 & 4.561 & 19.172 & 0.1438 & 0.143803 & 0.511894 & -14.51 & 0.510650 & -5.61 & 2135.66 & 2367.17 & 252.4 & 4.82 & 0.055235 & 0.704565 & 0.703522 & 8.62 \\
\hline N37-92 & 4.311 & 15.778 & 0.1652 & 0.165157 & 0.512482 & -3.04 & 0.511053 & 2.26 & 754.355 & 1690.68 & 273.5 & 8.86 & 0.093703 & 0.704049 & 0.702280 & -9.05 \\
\hline N66-92 & 3.460 & 13.162 & 0.1589 & 0.158905 & 0.512254 & -7.49 & 0.510879 & -1.13 & 1545.7 & 2070.06 & 249.7 & 35.49 & 0.411514 & 0.713776 & 0.706008 & 43.98 \\
\hline N80-92 & 11.067 & 63.174 & 0.1059 & 0.105869 & 0.511012 & -31.72 & 0.510096 & -16.44 & 2713.01 & 2742.88 & 644.1 & 12.1 & 0.054347 & 0.706645 & 0.705619 & 38.45 \\
\hline N274-93 & 2.097 & 5.701 & 0.2224 & 0.222412 & 0.513165 & 10.28 & 0.511241 & 5.95 & 3102.35 & 1786.4 & 112 & 0.86 & 0.022215 & 0.705485 & 0.705066 & 30.58 \\
\hline N224-93 & 3.588 & 13.891 & 0.1561 & 0.156114 & 0.512085 & -10.79 & 0.510735 & -3.96 & 2069.33 & 2369.6 & 189 & 2.94 & 0.045000 & 0.706219 & 0.705370 & 34.90 \\
\hline N210-93 & 1.672 & 10.518 & 0.0961 & 0.096084 & 0.511075 & -30.49 & 0.510244 & -13.56 & 2357.02 & 2456.21 & 127 & 59.54 & 1.360291 & 0.740156 & 0.714477 & 164.47 \\
\hline N324-93 & 6.747 & 28.115 & 0.1451 & 0.145065 & 0.511968 & -13.07 & 0.510713 & -4.38 & 1971.29 & 2260.83 & 181.5 & 11.46 & 0.182653 & 0.706681 & 0.703233 & 4.51 \\
\hline N277-93 & 8.617 & 47.091 & 0.0986 & 0.110598 & 0.511491 & -22.37 & 0.510534 & -7.89 & 2023.47 & 2211.59 & 560.4 & 33.69 & 0.174006 & 0.711460 & 0.708175 & 74.82 \\
\hline N266-92 & 5.541 & 27.084 & 0.1237 & 0.123651 & 0.51165 & -19.27 & 0.510580 & -6.98 & 2054.22 & 2259.34 & 499.7 & 18.29 & 0.105882 & 0.705689 & 0.703690 & 11.01 \\
\hline N220-92 & 2.615 & 8.544 & 0.1851 & 0.185059 & 0.512546 & -1.79 & 0.510945 & 0.16 & 1203.71 & 2333.18 & 147.4 & 4.47 & 0.087752 & 0.706383 & 0.704726 & 25.75 \\
\hline N115-92 & 6.866 & 30.137 & 0.1377 & 0.137707 & 0.511865 & -15.08 & 0.510674 & -5.15 & 1990.55 & 2249.03 & 394.6 & 1.31 & 0.009602 & 0.704790 & 0.704609 & 24.08 \\
\hline N262 & 13.995 & 73.414 & 0.1152 & 0.115211 & 0.511323 & -25.65 & 0.510326 & -11.94 & 2447.75 & 2543.16 & 899.6 & 3.16 & 0.010159 & 0.703169 & 0.702977 & 0.87 \\
\hline $\begin{array}{l}\text { N260 } \\
\quad \text { (gneiss) }\end{array}$ & 2.256 & 17.322 & 0.0787 & 0.078701 & 0.510466 & -42.37 & 0.509137 & -22.51 & 2788.93 & 2799.73 & 575.9 & 55.1 & 0.277104 & 0.718339 & 0.708080 & 95.33 \\
\hline $\begin{array}{l}\text { N264 } \\
\quad \text { (gneiss) }\end{array}$ & 0.492 & 4.538 & 0.0655 & 0.065492 & 0.510284 & -45.92 & 0.509178 & -23.84 & 2718.95 & 740.16 & 378 & 20.4 & 0.156220 & 0.712693 & 0.706910 & 78.64 \\
\hline
\end{tabular}

Notes: All Rb/Sr data were obtained on a MAT262 mass spectrometer. Analyses of NBS987 yielded $0.710202 \pm 22\left({ }^{87} \mathrm{Sr} /{ }^{86} \mathrm{Sr}, 1 \sigma, n=29\right)$. Nd data were obtained on a VG354 mass spectrometer. During the course of analysis on the VG354 the LaJolla standard yielded ${ }^{143} \mathrm{Nd} /{ }^{144} \mathrm{Nd}=0.511853 \pm 9(1 \sigma, n=48)$, and an NIGL internal standard gave ${ }^{143} \mathrm{Nd} /{ }^{144} \mathrm{Nd}=0.511125 \pm 7(1 \sigma, n=82)$. Blanks during the course of analyses were $<200 \mathrm{pg} \mathrm{Nd}$ and $<500 \mathrm{pg} \mathrm{Sr}$.

${ }^{a} \mathrm{Sm}$ and $\mathrm{Nd}$ concentration data were obtained by isotope dilution and measured to a precision of $\pm 0.1 \%$ ( $2 \sigma$ ), and $\mathrm{Rb}$ and $\mathrm{Sr}$ concentrations were measured by $\mathrm{X}$-ray fluorescence to a precision of $\pm 0.5 \%$.

${ }^{b}$ Present-day ${ }^{143} \mathrm{Nd} /{ }^{144} \mathrm{Nd}$ ratios; errors are \pm 2 standard errors of the mean. 
Table 3. Comparison of Sr- and Nd-isotope data for NPS intrusions, Nain dykes, and mafic granulites.

\begin{tabular}{|c|c|c|}
\hline & $\varepsilon_{\mathrm{Sr}}$ & $\varepsilon_{\mathrm{Nd}}$ \\
\hline $\begin{array}{l}\text { Marginal mafic } \\
\text { granulites }\end{array}$ & +10 to +403 & $\begin{array}{l}+0.74 \text { to }-11.4 \text { (with one at } \\
-17.1 \text { ) }\end{array}$ \\
\hline Nain dykes & +0.87 to +242 & +5.9 to -11.9 \\
\hline $\begin{array}{l}\text { NPS anorthosites } \\
\quad \text { (east) }\end{array}$ & +13 to +175.4 & -9.8 to $-14.8^{a}$ \\
\hline $\begin{array}{l}\text { NPS anorthosites } \\
\quad \text { (west) }\end{array}$ & +9.3 to +36.5 & -3.6 to $-8.7^{a}$ \\
\hline
\end{tabular}

${ }^{a}$ (data from Emslie et al. 1994 and Hamilton 1993)

samples taken from within major plutons) have a more limited range of $\varepsilon_{\mathrm{Sr}}$ than the marginal mafic granulites. Nevertheless, the marginal mafic granulite data are not anomalous in the light of data obtained for rocks from anorthosite pluton margins, for example at Higher Bight $\left(\varepsilon_{\mathrm{Sr}}=+64\right.$ to $+123)$, and an anorthositic dyke $\left(\varepsilon_{\mathrm{Sr}}=+463\right.$; Hamilton 1993). The Nain dykes (Cadman et al. 1998) also have a large range in initial $\varepsilon_{\mathrm{Sr}}$ values from -9 to +242 . The $\varepsilon_{\mathrm{Sr}}$ values of some dykes and marginal facies rocks are sufficiently high to suggest they are not primary, as has been concluded for some components of the NPS (Hamilton and Morse 1988; Hamilton 1993).

The Nd-isotope signatures of the marginal mafic granulites essentially fall within the range exhibited by the components of the NPS located in the Nain Province. The marginal mafic granulites from the southwestern margin of the Jonathon Island intrusion are the most varied, having $\varepsilon_{\mathrm{Nd}}$ values from +0.3 to -17.0 . The marginal mafic granulites from Nukasusutok Island have values from -4.0 to -11.0 (Tables 2, 3), akin to the observed range of the NPS anorthosites and associated rocks (Higher Bight and anorthositic dykes) of -3.7 to -14 (Ashwal et al. 1992; Hamilton 1993; Emslie et al. 1994). The Nain dykes have $\varepsilon_{\mathrm{Nd}}$ values in the range +5.9 to -3.8 , distinct from most NPS rocks, although the $\varepsilon_{\mathrm{Nd}}$ value of 5.9 for this unit is the only value above depleted mantle.

\section{Crustal contamination of marginal mafic granulites and Nain dykes}

The $\varepsilon_{\mathrm{Nd}}$ values for the Nain dykes and marginal mafic granulites are significantly lower than depleted mantle and are clearly not solely derived from a simple mantle reservoir. A satisfactory interpretation of the data for the marginal mafic granulites and Nain dykes therefore requires an assessment of the role of crustal contamination to investigate the mechanisms responsible for the production of negative $\varepsilon_{\mathrm{Nd}}$ and extremely positive $\varepsilon_{\mathrm{Sr}}$ values. A similar interpretation was reached for the NPS anorthosites (Hamilton 1993, 1987).

The predominantly granitic Archaean and Proterozoic NPS country rocks had much higher REE contents and more negative $\varepsilon_{\mathrm{Nd}}$ values than the NPS (Hamilton 1993), Nain dykes, or marginal mafic granulites, indicating that only a small amount of assimilation would significantly modify the $\varepsilon_{\mathrm{Nd}}$ signature of these rocks. Figure 3 presents mixing relations of a hypothetical mafic melt derived from depleted mantle with Nain Province Archaean and Proterozoic rocks.
Fig. 3. ${ }^{143} \mathrm{Nd} /{ }^{144} \mathrm{Nd}$ vs. $\mathrm{Nd}$ illustrating calculated mixing hyperbole for contaminants A (Archaean tonalite) and B (Proterozoic granitoid gneiss), with a primary asthenospheric magma (see Hamilton 1993).

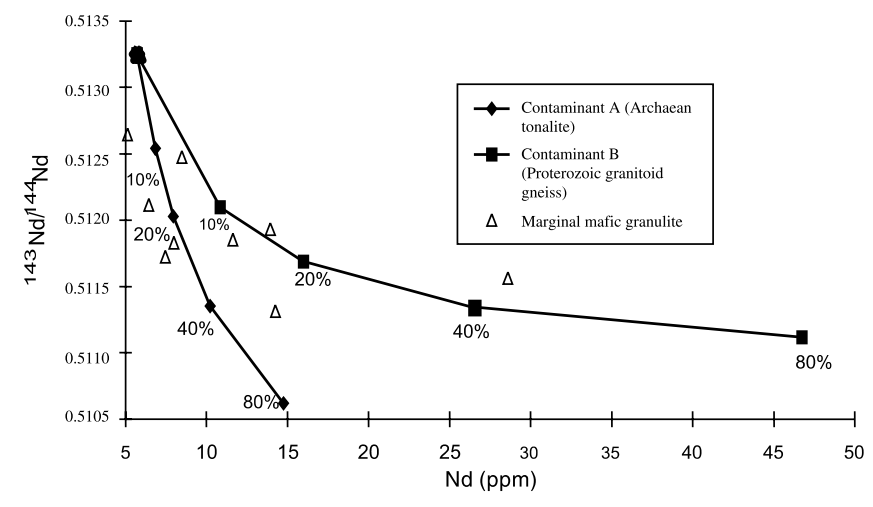

The ${ }^{143} \mathrm{Nd} /{ }^{144} \mathrm{Nd}$ ratio and $\mathrm{Nd}$ concentration of mixtures can be calculated using

$$
\begin{aligned}
\left({ }^{143} \mathrm{Nd} /{ }^{144} \mathrm{Nd}\right)_{m} & =\left({ }^{143} \mathrm{Nd} /{ }^{144} \mathrm{Nd}\right)_{\mathrm{a}}\left(\mathrm{Nd}_{\mathrm{a}} f / \mathrm{Nd}_{m}\right) \\
& +\left({ }^{143} \mathrm{Nd} /{ }^{144} \mathrm{Nd}\right)_{\mathrm{b}}\left[\mathrm{Nd}_{\mathrm{b}}(1-f) / \mathrm{Nd}_{m}\right]
\end{aligned}
$$$$
\text { [2] } \quad \mathrm{Nd}_{m}=\mathrm{Nd}_{\mathrm{a}} f+\mathrm{Nd}_{\mathrm{b}}(1-f)
$$

where $\mathrm{a}$ and $\mathrm{b}$ are the components being mixed together, e.g., NPS anorthosite and country-rock gneisses; $m$ is the resultant mixture; and $f$ is the proportion of a in the mixture (DePaolo 1981). Country-rock compositions used here are Archaean tonalitic migmatized gneiss (contaminant A) and Proterozoic granitoid gneiss (contaminant B) taken from Hamilton (1993). Figure 3 shows that even small amounts (approx. 10\%) of gneiss shift the Nd-isotope ratios of an asthenospheric melt a considerable degree away from depleted mantle.

Simple binary mixing equations (Langmuir et al. 1978) were used to calculate the relative proportions of crustal and mantle components to further examine the effects of contamination, particularly as it effects $\mathrm{Sr}$ isotopes. Binary mixing can be described by the equation

$$
\mathrm{R}_{\mathrm{m}}^{x}=\mathrm{R}_{\mathrm{a}}^{x} X_{\mathrm{a}} f+\mathrm{R}_{\mathrm{b}}^{x} X_{\mathrm{b}}(1-f) / X_{\mathrm{a}} f+X_{\mathrm{b}}(1-f)
$$

where $\mathrm{R}_{\mathrm{m}}^{x}$ is an isotope ratio of $X$ in a mixture of components a and b; $X_{\mathrm{b}}$ and $X_{\mathrm{a}}$ are the concentrations of $X$ in a and $\mathrm{b}$, respectively; and $f$ is the weight fraction of a. In this case $\mathrm{Nd}$ - and Sr-isotope ratios for the marginal mafic granulites and the country-rock gneisses are compared. A depleted mantle isotopic composition of $\varepsilon_{\mathrm{Nd}}=+2,{ }^{87} \mathrm{Sr}^{86}{ }^{86} \mathrm{Sr}_{\mathrm{i}}=0.7026$ at $1.3 \mathrm{Ga}$ (Taylor and McLennan 1981; Albarède and Brouxel 1987) is used to represent hypothetical initial conditions of a NPS asthenospheric melt prior to interaction with the crust. A depleted mantle composition is a reasonable starting condition given that it is approximately equivalent to the potentially least modified signature observed for the Nain dykes $\left(\varepsilon_{\mathrm{Nd}}=+2.26,{ }^{87} \mathrm{Sr} /{ }^{86} \mathrm{Sr}_{\mathrm{i}}=0.702\right.$; Cadman et al. 1999). The end-member Sr- and Nd-isotope compositions for the country-rock gneisses of the Nain Province are those of Hamilton (1993).

Figure 4 illustrates isotope mixing lines on an $\varepsilon_{\mathrm{Sr}}$ versus $\varepsilon_{\mathrm{Nd}}$ diagram for Archaean and Proterozoic country-rock con- 
Fig. 4. $\varepsilon_{\mathrm{Nd}}$ vs. $\varepsilon_{\mathrm{Sr}}$ diagram displaying mixing hyperbolas for the mafic granulites. Trajectories shown are for contaminants A (Archaean tonalite) and B (Proterozoic granitoid gneiss) mixing with a primary asthenospheric magma. DM, depleted mantle quadrant.

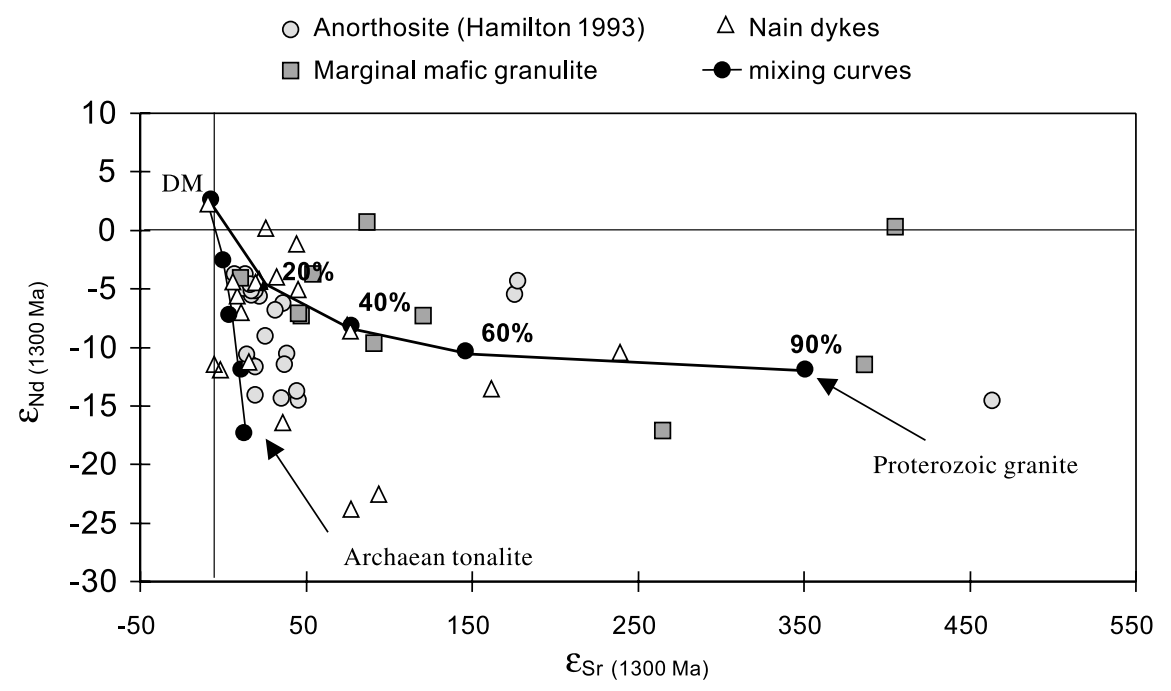

taminants and depleted mantle. Contaminants A and B are the same as in Fig. 3. Most of the available data for NPS anorthosites, and some of the marginal mafic granulites and the Nain dykes, have $\varepsilon_{\mathrm{Sr}}$ versus $\varepsilon_{\mathrm{Nd}}$ values that plot between the mixing curves for depleted mantle, Archaean and Proterozoic gneisses and thus could be explained in terms of local country rock contamination. The most primitive members of the array can be accounted for by as little as $10 \%$ bulk assimilation of crustal material. The more extreme apparent contamination levels involving Proterozoic crust, however, require at least $40 \%$ crustal assimilation. Such levels of assimilation are completely unrealistic, as the bulk composition of the rocks would be modified to excessively felsic compositions. Furthermore, several marginal mafic granulites samples have $\varepsilon_{\mathrm{Sr}}$ values higher than that of any Proterozoic and Archaean gneisses proximal to the NPS but do not have correspondingly negative $\varepsilon_{\mathrm{Nd}}$ ratios. The high $\varepsilon_{\mathrm{Sr}}$ values and apparent decoupling of $\mathrm{Sr}$ and $\mathrm{Nd}$ isotopes indicates that bulk contamination of a depleted mantle source with gneisses presently exposed in the Nain Province is not adequate in explaining the isotope characteristics of the Nain dykes and marginal mafic granulites.

A number of mechanisms could account for the fact that marginal mafic granulites, Nain dykes, and the NPS anorthosites do not follow a single mixing path. Assimilation of a wide range of rock types with varied composition or concurrent assimilation and fractional crystallization (AFC; DePaolo 1981) could have occurred, but both are unlikely. First, assimilation would require availability of high$\varepsilon_{\mathrm{Sr}}$, low- $\varepsilon_{\mathrm{Nd}}$ material, probably with relatively mafic major element chemistry so that the final bulk geochemical composition is not shifted to an intermediate to felsic composition. Rocks within the Nain Province with $\varepsilon_{\text {Sr }}$ in excess of +500 have not been reported, but would be necessary to produce the high $\varepsilon_{\mathrm{Sr}}$ values observed in some of the mafic granulites. Second, low temperatures $\left(200-300^{\circ} \mathrm{C}, 6-14 \mathrm{~km}\right.$; Berg 1977) of the crust, far below that of mantle melts, would result in rapid heat loss and crystallization of the assimilating magma. AFC does not appear to be a viable mechanism, therefore, because wholesale assimilation of cold crust would result in rapid freezing, precluding continuation of fractionation. The Nd signatures of anorthosites and marginal mafic granulites are consistent with derivation by partial melting of an asthenospheric mantle source (DePaolo 1981; Hamilton 1993). If the marginal mafic granulites are indeed related to the NPS, then they have the most primitive $\mathrm{Nd}$ signatures so far recorded in the NPS $\left(\varepsilon_{\mathrm{Nd}}=0.74\right.$ for the marginal mafic rocks). To summarize, the $\varepsilon_{\mathrm{Nd}}$ values of the marginal mafic granulite and the Nain dykes can be adequately accounted for by contamination with gneisses of the Nain Province. This is similar to the scenario proposed for NPS anorthosites by Hamilton (1993). Those samples which possess very high $\varepsilon_{S r}$ values but do not have correspondingly negative $\varepsilon_{\mathrm{Nd}}$ ratios cannot be accounted for in this model.

\section{Origin of high $\varepsilon_{\mathrm{Sr}}$ values in mafic granulites}

Contamination of the marginal mafic granulites by a high$\varepsilon_{\mathrm{Sr}}$ source, without imposing significant changes to the major element content of the granulites, requires a selective contribution of $\mathrm{Sr}$ from a high- $\varepsilon_{\mathrm{Sr}}$, Sr-rich reservoir. The production of magmas with high $\varepsilon_{\mathrm{Sr}}$ values by contamination with a Sr-rich source has been documented in subduction-related systems, where fluids have introduced $\mathrm{Sr}$ ultimately derived from seawater (O'Nions et al. 1978). A similar process is unlikely in the case of the marginal mafic granulites because the rocks of the Nain area are anhydrous and not subduction related (Berg 1976, 1977; Morse 1982). Nevertheless, local sources of appropriate $\mathrm{Sr}$ are available to the marginal mafic granulites. Krogh and Davis (1973) and Collerson (1982) noted that $\mathrm{Sr}$ migrated over relatively short distances during amphibolite-facies metamorphism, driven by chemical gradients existing between rock layers with strongly contrasting chemical composition. It is possible that a similar process could have introduced $\mathrm{Sr}$ with a high $\varepsilon_{\mathrm{Sr}}$ signature from the host gneisses into the marginal mafic granulites.

Patchett (1980) suggested that one of the most effective methods of contamination in basaltic sheets is the breakdown of hydrous minerals (particularly significantly older sheet silicates) in the surrounding country rock. In the case of the marginal mafic granulites, the most plausible source 
Fig. 5. All analyzed samples from the NPS plotted on an ${ }^{87} \mathrm{Sr} /{ }^{86} \mathrm{Sr}$ vs. Sr diagram. Data points for the anorthosites are from Hamilton (1993) and for the Nain dykes from Cadman et al. (1999). The data suggest that not only the marginal granulites, but also the margins of the anorthosites and the dykes have been affected by thermal breakdown of biotite in the host rocks and transport of accumulated radiogenic $\mathrm{Sr}$ by metasomatic fluids.

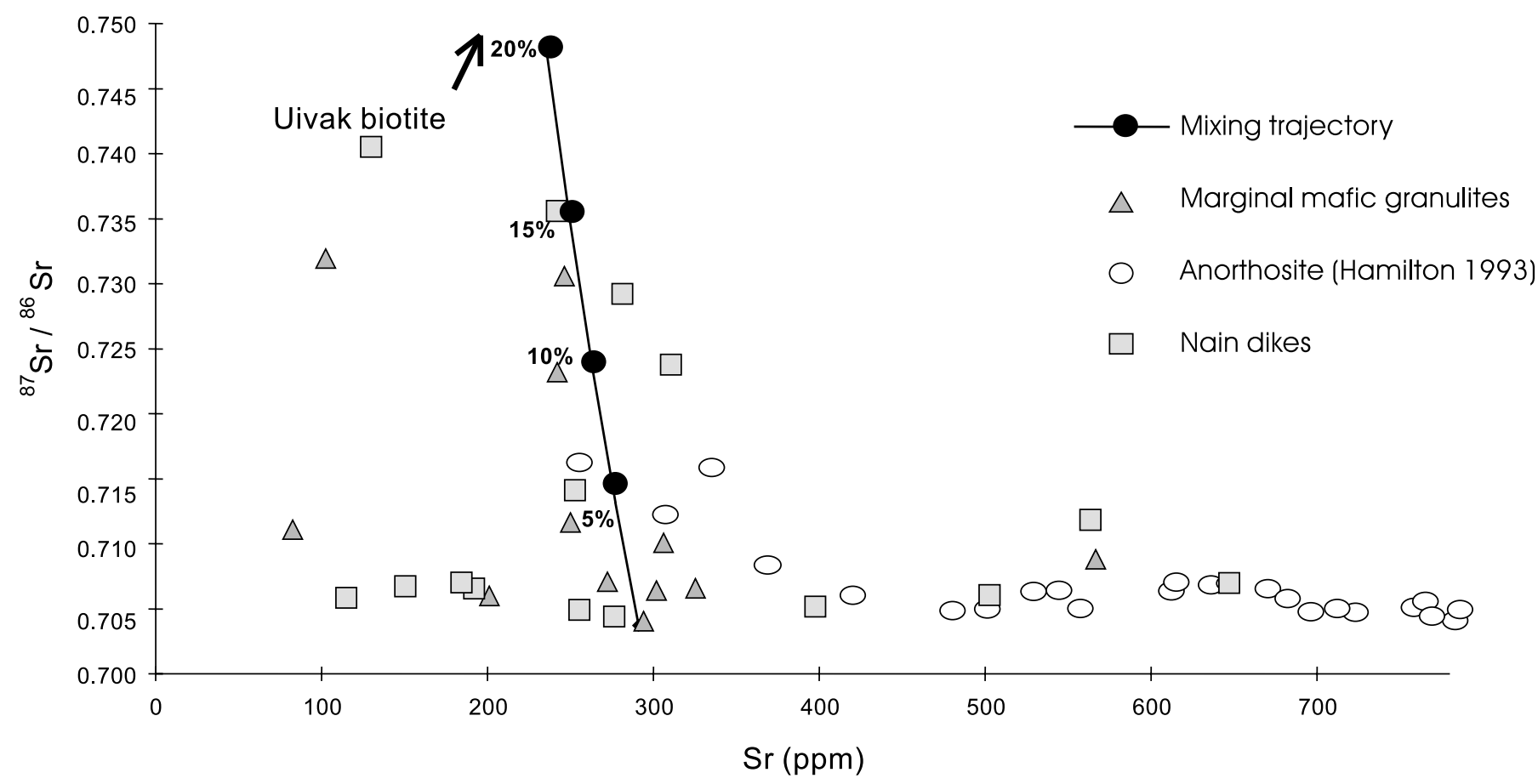

Fig. 6. Phase diagram of the mafic granulites and Al-Fe-rich gabbros found in other massif-type anorthosite terrains. It is noteworthy that all their bulk compositions cluster near the point of multiple saturation with olivine, plagioclase, and orthopyroxene. All projected from wollastonite onto the olivine-plagioclase-silica plane (Longhi 1991).

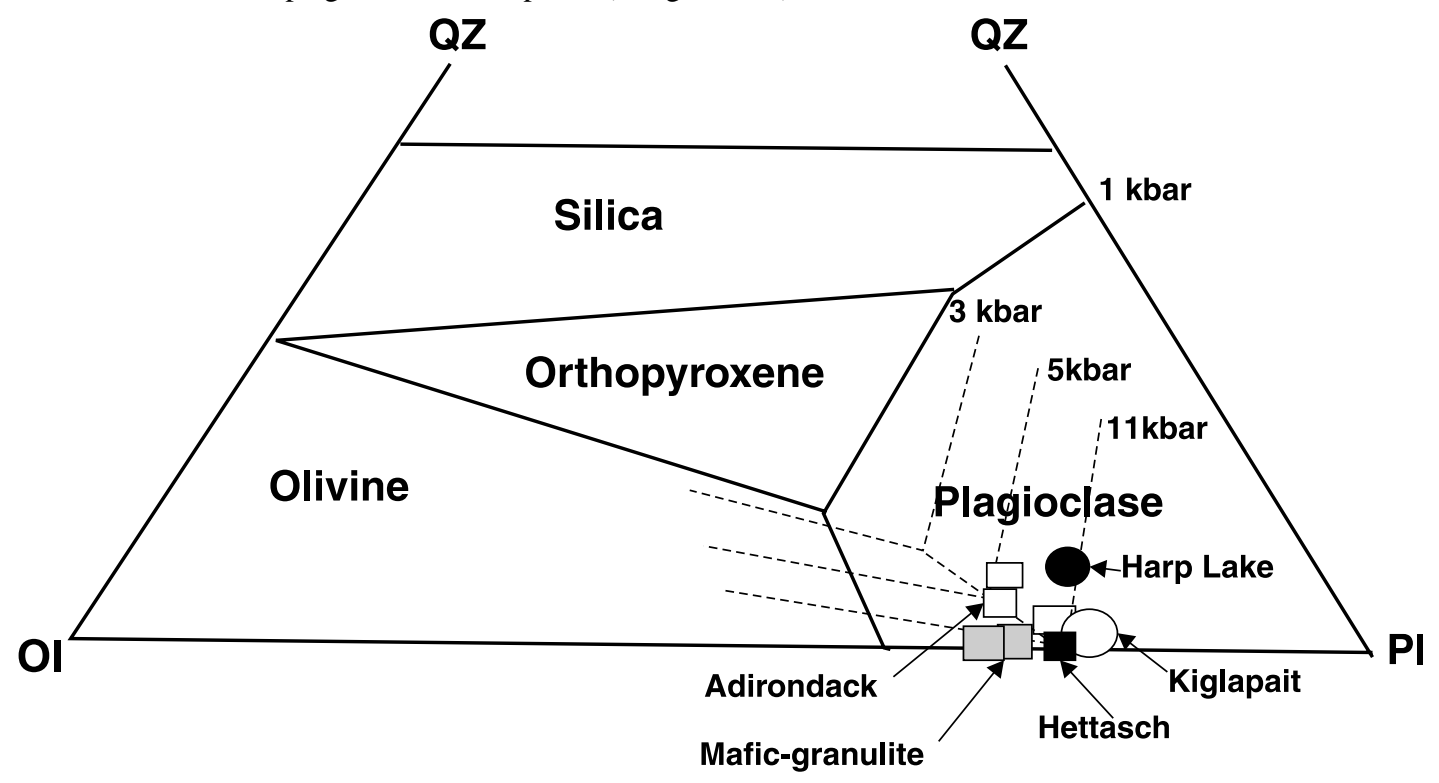

of $\mathrm{Sr}$ with a high $\varepsilon_{\mathrm{Sr}}$ available is biotite from the country rocks, particularly the ca. $2.5 \mathrm{Ga}$ schlieric granitoid gneisses (Ryan 1992, 1993). The biotite is likely to have experienced breakdown during high-temperature pyroxene-hornfels facies contact metamorphism associated with NPS intrusion. The biotite in the gneisses would have developed a high $\varepsilon_{\mathrm{Sr}}$ signature relative to the host gneiss between the late Archaean and the time of NPS intrusion because of its high $\mathrm{Rb} / \mathrm{Sr}$ ratio. Breakdown of biotite during metamorphism would result in the release of $\mathrm{Rb}$ and $\mathrm{Sr}$ which would then be available to the mafic granulites, possibly via a metamorphic fluid phase derived from the gneisses. The Sm-Nd 
characteristics of the marginal mafic granulites would not have been influenced because $\mathrm{Sm}$ and $\mathrm{Nd}$ are not major components of biotite. Plagioclase crystallizing in the mafic granulites adjacent to the gneisses would have been a sink for $\mathrm{Sr}$ from biotite breakdown, but no mineral phase crystallized to accept $\mathrm{Rb}$. As a consequence, $\mathrm{Rb}$ would have become decoupled from $\mathrm{Sr}$ and the marginal rocks would have been progressively enriched in apparently unsupported radiogenic Sr. Biotite is sufficiently enriched in $\mathrm{Sr}$ such that only volumetrically small amounts (up to $15 \mathrm{wt} . \%$ ) of biotite $\mathrm{Sr}$ would have been required to produce the observed increase in Sr within the marginal mafic granulites (Fig. 5). A similar scenario has been proposed for dykes in the Saglek Block (Collerson et al. 1984) and could also apply to those NPS anorthositic rocks (Higher Bight and the anorthosite dykes; Hamilton 1993) and the Nain dykes which have particularly high $\varepsilon_{\mathrm{Sr}}$ and $\varepsilon_{\mathrm{Nd}} \approx 0$. It is possible that this effect occurred in other NPS anorthosites and associated ferrodiorites, but their more negative $\varepsilon_{\mathrm{Nd}}$ values makes the detection of anomalously elevated $\varepsilon_{\mathrm{Sr}}$ values difficult.

\section{Implications to petrogenesis of the NPS}

Olson and Morse (1990) have noted that many anorthosite complexes contain rocks with unusually high $\mathrm{Al}_{2} \mathrm{O}_{3}$ (5-15 wt.\%) and $\mathrm{Fe}_{2} \mathrm{O}_{3}$ (11.6-18 wt.\%). Most of the $\mathrm{Al}_{2} \mathrm{O}_{3}$ and $\mathrm{Fe}_{2} \mathrm{O}_{3}$ contents for the marginal mafic granulites and Nain dykes fall within these ranges. The bulk compositions of the marginal mafic granulites are tightly clustered near the point of multiple saturation with plagioclase, olivine, and orthopyroxene between 11.5 and $15 \mathrm{kbar}(1 \mathrm{kbar}=100 \mathrm{MPa})$ on an olivine-silica-plagioclase phase diagram (Fig. 6) (after Longhi 1991). It is noteworthy that Al-Fe-rich gabbros found in the Laramie, Harp Lake, Adirondacks, and Kiglapait intrusions all plot in broadly the same area (Fig. 6) (Olson and Morse 1990).

It has long been suspected that high-Al-Fe mafic magmas have an important connection with massif-type anorthosites and their parental magmas (Emslie 1978a, 1978b, 1980; Morse 1982; Olson and Morse 1990). Fram and Longhi (1992) indicated it is not possible for high-Al-Fe mafic magmas to directly produce the amounts of plagioclase in anorthosite by fractional crystallization, thus implying mechanical enrichment of plagioclase. Alternatively, polybaric crystallization (cf. Longhi and Ashwal 1985; Emslie et al. 1994) could account for the large amounts of plagioclase. For instance, at $10 \mathrm{kbar}$ olivine, plagioclase, and orthopyroxene coexist at the eutectic point. However, at $15 \mathrm{kbar}$ a peritectic exists between olivine, orthopyroxene, and spinel such that the plagioclase component in the remaining liquid will increase as crystallization proceeds. If the liquid intruded upwards, pressure decreases and plagioclase is the sole liquidus phase (Morse 1979). The parental liquids of anorthositic intrusions would therefore have lower normative plagioclase compositions than would be calculated for the anorthositic intrusions (Morse 1979).

\section{Conclusions}

The marginal mafic granulites from the NPS exposed on Nukasusutok Island and Jonathon Island are interpreted to be an integral part of the NPS on the basis of their field rela- tionships (diffuse contacts with NPS anorthosites, distinct nature compared to Archaean hornblende-bearing granulites), their major element characteristics, and their Sr-Ndisotope systematics. The phase relationships of the marginal mafic granulites are similar to $\mathrm{Al}-\mathrm{Fe}$-rich gabbros from the Laramie, Harp Lake, and Adirondack anorthosite massifs. It is suggested that the marginal mafic granulites may be a reasonable approximation to the parental magma to the NPS.

The marginal mafic granulites, as well as the 1328-1317 Ma Nain dykes, possess a wide range of initial $\mathrm{Sr}$ and $\mathrm{Nd}$ signatures that generally overlap with those observed in the margins of the NPS anorthosites (Hamilton 1993; Emslie et al. 1994). The isotope characteristics of many of the dykes and marginal mafic granulites can be adequately accounted for by contamination with gneisses of the Nain Province as proposed for NPS anorthosites by Hamilton (1993). Some marginal mafic granulites, however, possess very high $\varepsilon_{\mathrm{Sr}}$ values but do not have correspondingly negative $\varepsilon_{\mathrm{Nd}}$ ratios typical of crustally contaminated mafic magmas. It is proposed that their Sr-isotope signatures are the result of the selective introduction of $\mathrm{Sr}$ derived from the breakdown of biotite in the host Archaean gneisses during pyroxenehornfels facies contact metamorphism.

\section{Acknowledgments}

K.R.R. gratefully acknowledges support from a Natural Environment Research Council studentship and logistical support in the field provided by the Newfoundland Department of Mines and Energy. K.R.R. would particularly like to thank Bruce Ryan and field assistants John Royse and Ed Brown. We are indebted to J.N. Connelly and D.J. Scott for their incisive and helpful reviews.

\section{References}

Albarède, F., and Brouxel, M. 1987. The Sm/Nd secular evolution of the continental crust and the depleted mantle. Earth and Planetary Science Letters, 82: 25-35.

Ashwal, L.D., and Seifert, K.E. 1980. Rare earth element geochemistry of anorthosite and related rocks from the Adirondacks, New York, and other massif-type complexes. Geological Society of America Bulletin, 91: 105-107, 659-684

Ashwal, L.D., and Wooden, J.L. 1983. Sr and $\mathrm{Nd}$ isotope geochronology, geologic history, and origin of the Adirondack Anorthosite. Geochimica et Cosmochimica Acta, 47: 1875-1885.

Ashwal, L.D., Wiebe, R.A., Wooden, J.L., Whitehouse, M.J., and Snyder, D. 1992. Pre-Elsonian mafic magmatism in the Nain igneous complex, Labrador: the Bridges layered intrusion. Precambrian Research, 56: 73-87.

Berg, J.H. 1976. Metamorphosed mafic and ultramafic rocks in the contact aureoles of the Nain complex, Labrador, and the miscibility gap between spinel and magnetite in natural $\mathrm{Cr}-\mathrm{Al}-\mathrm{Ti}$ spinels. Geological Society of America, Abstracts with Programs, 8: $773-774$.

Berg, J.H. 1977. Regional geobarometry in the contact aureoles of the anorthositic Nain complex, Labrador. Journal of Petrology, 18: 399-430.

Berg, J.H., Emslie, R.F., Hamilton, M.A., Morse, S.A., Ryan, A.B., and Wiebe, R.A. 1994. Anorthositic, granitoid and related rocks of the Nain plutonic suite. Field excursion to the Nain area. In- 
ternational Geological Correlation Programme, IGCP Projects 290 and 315.

Bridgwater, D., and Schiøtte, L. 1991. The Archaean gneiss complex of Northern Labrador: a review of current results, ideas and problems. Bulletin of the Geological Society of Denmark, 39: 153-166.

Cadman, A.C., and Ryan, B. 1994. An investigation of some metamorphosed dykes of the Nain area, Labrador, part 2. Geochemistry of the Akkuneq Dykes of the Dog Island Region. In Current research (1994). Newfoundland Department of Mines and Energy, Geological Survey Branch, Report 94-1, pp. 333345.

Cadman, A.C., Harris, D., and Ryan, B. 1993. An investigation of some metamorphosed mafic dykes of the Nain area, Labrador. In Current research (1993). Newfoundland Department of Mines and Energy, Geological Survey Branch, Report 93-1, pp. 1-15.

Cadman, A.C., Ryan, B., Royse, K.R., and Noble, S.R. 1995, An investigation of some metamorphosed dykes of the Nain area: part 3 - Geochemistry and structural relationships of dykes in the Nukasusutok Island area. In Current research (1995). Newfoundland Department of Natural Resources, Geological Survey, Report 95-1, pp. 1-14.

Cadman, A.C., Noble, S.R., Tarney, J., Park, R.G., Ryan, A.B., and Royse, K.R. 1999. U-Pb ages of syn-deformational dykes associated with the Mesoproterozoic Nain Plutonic Suite, Labrador. Canadian Journal of Earth Sciences, 36: 339-348.

Collerson, K.D. 1982. The Archaean gneiss complex of northern Labrador. 2. Mineral ages, secondary isochrons, and diffusion of strontium during polymetamorphism of the Uivak gneisses. Canadian Journal of Earth Sciences, 20: 707-718.

Collerson, K.D., McCulloch, M.T., and Bridgwater, D. 1984. Nd and $\mathrm{Sr}$ isotopic crustal contamination patterns in an Archaean meta-basic dyke from northern Labrador. Geochimica et Cosmochimica Acta, 48: 71-83.

Connelly, J.N., and Ryan, B. 1993. U-Pb constraints on the thermotectonic history of the Nain area. In Eastern Canadian Onshore-Offshore Transect (ECSOOT), Report of Transect Meeting, 4-5 December 1992. Edited by R.J. Wardle and J. Hall. University of British Columbia, Lithoprobe Secretariat, Report 32, pp. 137-144.

Connelly, J.N., and Ryan, B. 1994. Late Archaean and Proterozoic events in the central Nain craton. In Eastern Canadian OnshoreOffshore Transect (ECSOOT), Report of Transect Meeting, 1011 December 1993. Edited by J. Hall and R.J. Wardle. University of British Columbia, Lithoprobe Secretariat, Report 36, pp. 53-61.

Connelly, J.N., and Ryan, B. 1996. Late Archaean evolution of the Nain province, Nain, Labrador: imprint of a collision. Canadian Journal of Earth Sciences, 33: 1325-1342.

DePaolo, D.J. 1981. Trace element and isotopic effects of combined wall rock assimilation and fractional crystallisation. Earth and Planetary Science Letters, 53: 189-202.

Duchesne, J.-C. 1978. Quantitative modelling of Sr, Ca, Rb, and K in the Bjerkrem-Sogndal layered lopolith (S.W. Norway). Contributions to Mineralogy and Petrology, 66: 175-184.

Emslie, R.F. 1978a. Anorthosite massifs, rapakivi granites and late Proterozoic rifting of North America. Precambrian Research, 7: 61-98.

Emslie, R.F. 1978b. Elsonian magmatism in Labrador: age, characteristics, and tectonic settings. Canadian Journal of Earth Sciences, 15: 438-453.

Emslie, R.F. 1980. Geology and petrology of the Harp Lake complex, central Labrador: an example of Elsonian magmatism. Geological Survey of Canada Bulletin 293.
Emslie, R.F., Morse, S.A., and Wheeler, E.P. 1972. Igneous rocks of central Labrador with emphasis on anorthositic and related intrusions. 24th International Geological Congress, Guidebook, Field Excursion A54.

Emslie, R.F., Hamilton M.A., and Theriault, R.J. 1994. Petrogenesis of a Mid-Proterozoic anorthosite-mangerite-charnockitegranite (AMCG) complex: isotopic and chemical evidence from the Nain Plutonic Suite. Journal of Geology, 102: 539-558.

Ermanovics, I.F., Van Kranendonk, M., Corriveau, L., Mengel, F., Bridgwater, D., and Sherlock, R. 1989. The boundary zone of the Nain-Churchill provinces in the North River - Nutak map areas, Labrador. In Current research, part C. Geological Survey of Canada, Paper 89-1C, pp. 385-394.

Fram, M.S., and Longhi, J. 1992. Phase equilibria of dykes associated with Proterozoic anorthosite complexes. American Mineralogist. 77: 605-616.

Hamilton, M.A. 1987. Geochemistry of Archaean and Proterozoic rocks of the central Nain Province Labrador: implications for contamination of Elsonian magmas. Geological Association of Canada, Abstracts with Programs, 19: 691.

Hamilton, M.A. 1993. Contamination of massif anorthosite and Precambrian crustal evolution in central Labrador: a combined trace element and $\mathrm{Sr}, \mathrm{Nd}$ and $\mathrm{Pb}$ isotopic study. $\mathrm{Ph} . \mathrm{D}$. thesis, University of Massachusetts, Boston.

Hamilton, M.A., and Morse, S.A. 1988. 2.3 Ga source enrichment of Labrador anorthosites and gabbros. Geological Association of Canada - Mineralogical Association of Canada - Canadian Society of Petroleum Geologists, Program with Abstracts, 13: A51.

Hamilton, M.A., and Shirey, S.B. 1992. Nd and Sr isotopic variations in anorthositic rocks of the Nain Plutonic Suite, Labrador. American Geophysical Union, Spring Annual General Meeting, Montréal (Transactions of the American Geophysical Union), 73: 355 and supplement.

Isachsen, Y.W. (Editor). 1968. Origin of anorthosite and related rocks. New York State Museum and Science Service, Memoir 18.

Krogh, T.E., and Davis, G.L. 1973. The effect of regional metamorphism on U-Pb systems in zircon and a comparison with $\mathrm{Rb}-\mathrm{Sr}$ systems in the same whole rock and its constituent minerals. Carnegie Institution of Washington Yearbook, 72: 601610.

Langmuir, C.H., Vocke, R.D., Hanson, G.N., and Hart, S.R. 1978. A general mixing equation with applications to Icelandic basalts. Earth and Planetary Science Letters, 37: 380-407.

Longhi, J. 1991. Comparative liquidus equilibria of hypersthenenormative basalts at low pressure. American Mineralogist, 76: 785-800.

Longhi, J., and Ashwal, L.D. 1985. Two stage models for Lunar and terrestrial anorthosites: petrogenesis without a magma ocean. Proceedings of the 15th Lunar and Planetary Science Conference, Part 2. Journal of Geophysical Research, 90 (suppl.): C571-C584.

Marsh, N.G., Tarney, J., and Hendry, G.L. 1983. Trace element geochemistry of basalts from hole 504B, Panama Basin, DSDP Legs 69 \& 70. Initial Reports of the Deep Sea Drilling Project, 69: $747-764$.

McCulloch, M.T., Jaques, A.L., Nelson, D.R., and Lewis, J.D. 1983. $\mathrm{Nd}$ and $\mathrm{Sr}$ isotopes in kimberlites and lamproites from western Australia: enriched mantle origin. Nature (London), 302: 400-403.

Morse, S.A. 1971-1983. The Nain Anorthosite Project, Labrador: field reports. Department of Geology, University of Massachusetts, Amherst, Mass., Contributions 9, 11, 13, 17, 26, 29, 38, and 40 . 
Morse, S.A. 1979. Kiglapait geochemistry I: Systematics, sampling and density. Journal of Petrology, 20: 555-590.

Morse, S.A. 1982. A partisan review of Proterozoic anorthosites. American Mineralogist, 67: 1087-1100.

Nolan, K.M., and Morse, S.A. 1986. Marginal rocks resembling the estimated bulk composition of the Kiglapait Intrusion. Geochimica et Cosmochimica Acta, 50: 2381-2386.

Olson, K.E., and Morse, S.A. 1990. Regional Al-Fe mafic magmas associated with anorthosite-bearing terranes. Nature (London), 344: 760-762.

O’Nions, R.K., Carter, S.R., Cohen, R.S., Evensen, N.M., and Hamilton, P.J. 1978. $\mathrm{Pb}, \mathrm{Nd}$ and $\mathrm{Sr}$ isotopes in oceanic ferromanganese deposits and ocean floor basalts. Nature (London), 273: 435-538.

Patchett, P.J. 1980. Thermal effects of basalt on continental crust and crustal contamination of magmas. Nature (London), 283: 559-561.

Pearce, J.A. 1983. Role of the sub-continental lithosphere in magma genesis at active continental margins. In Continental basalts and mantle xenoliths. Edited by C.J. Hawkesworth and M.J. Norry. Shiva Publications, Nantwich, U.K., pp. 230-249.

Royse, K.R., and Ryan, B. 1995, Structural evolution and emplacement of the Nain Plutonic Suite in the Dog Island area. In Current research (1995). Newfoundland Department of Natural Resources, Geological Survey Branch, Report 95-1, pp. 37-45.

Ryan, B. 1990. Preliminary geological map of the Nain Plutonic Suite and surrounding rocks (Nain-Nutak, NTS $14^{\circ} \mathrm{SW}$ ). Newfoundland Department of Mines and Energy, Geological Survey Branch, Map 90-44, scale 1 : 500000.

Ryan, B. 1991. New perspectives on the Nain Plutonic Suite and its country rocks. In Current research (1991). Newfoundland Department of Mines and Energy, Geological Survey Branch, Report 91-1, pp. 231-255.

Ryan, B. 1992. Nain area geology: observations on selected islands, and the area south of Nain bay. In Current research (1992). Newfoundland Department of Mines and Energy, Geological Survey Branch, Report 92-1, pp. 381-398.

Ryan, B. 1993. Further results of mapping gneissic and plutonic rocks of the Nain area, Labrador. In Current research (1993). Newfoundland Department of Mines and Energy, Geological Survey Branch, Report 93-1, pp. 61-75.
Ryan, B. 1995. Morphological features of multigenerational basic dykes near Nain Labrador: clues to the original emplacement mechanisms and subsequent deformation. Precambrian Research, 75: 91-118.

Ryan, A.B., and Emslie, R.F. 1994. Pre-Elsonian mafic magmatism in the Nain igneous complex, Labrador: the Bridges layered intrusion - comment. Precambrian Research, 68: 179-181.

Shirey, S.B., and Hanson, G.N. 1986. Mantle heterogeneity and crustal recycling in Archaean granite greenstone belts: evidence from $\mathrm{Nd}$ isotopes and trace elements in the Rainy Lake area, Ontario. Geochimica et Cosmochimica Acta, 50: 2631-2651.

Stager, R.H., and Jäger, E. 1977. Subcommission on geochronology: convention on the use of decay constants in geo- and cosmochronology. Earth and Planetary Science Letters, 36: 359362.

Taylor, F.C. 1979. Reconnaissance geology of a part of the Precambrian shield, north-eastern Quebec, Northern Labrador and Northwest Territories. Geological Survey of Canada, Memoir 393.

Taylor, S.R., and McLennan, S.M. 1981. The continental crust: its composition and evolution. Blackwell, Oxford.

Wardle, R.J., Ryan, B., Nunn, G.A.C., and Mengel, F.C. 1990. Labrador segment of the Trans-Hudson orogen: crustal development through oblique convergence and collision. In The early Proterozoic Trans-Hudson orogen of North America. Edited by J.F. Lewry and M.R. Stauffer. Geological Association of Canada, Special Paper 37, pp. 353-369.

Watson, E.B. 1979. Apatite saturation in basic to intermediate magmas. Geophysical Research Letters, 6: 939-940.

Wheeler, E.P. 1942. Anorthosite and related rocks about Nain Labrador coasts. Journal of Geology, 50: 611-642.

Wheeler, E.P. 1960. Anorthosite-adamellite complex of Nain, Labrador. Bulletin of the Geological Society of America, 71: 17551762 .

Wiebe, R.A. 1992. Proterozoic anorthosite complexes. In Proterozoic crustal evolution. Chapt. 6. Edited by K.C. Condie. Elsevier, Amsterdam, pp. 215-261.

Xue, S., and Morse, S.A. 1993. Geochemistry of the Nain anorthosite, Labrador: magma diversity in five intrusions. Geochimica et Cosmochimica Acta, 57: 3925-3948. 